\title{
Partitioning of Dry Matter in Different Rice Varieties in Response to Water Logged and Submerged Condition
}

\author{
B. Das ${ }^{1}$, A.K. Padhiary ${ }^{2 *}$, S. Behera ${ }^{3}$, S.P. Mishra ${ }^{4}$, M. Jena ${ }^{5}$, S.C. Swain ${ }^{6}$ and S.K. Rout $^{1}$ \\ ${ }^{1}$ College of Agriculture, Bhubaneswar, Odisha, India \\ ${ }^{2}$ Krishi Vigyan Kendra, Sambalpur, Odisha, India \\ ${ }^{3}$ Krishi Vigyan Kendra, Kalahandi, Odisha, India \\ ${ }^{4}$ Krishi Vigyan Kendra, Jagatsingpur, Odisha, India \\ ${ }^{5}$ Agro polytechnic Centre, Ranital, Bhadrak, Odisha, India \\ ${ }^{6}$ Agro polytechnic Centre, Rangeilunda, Odisha, India \\ *Corresponding author
}

A B S T R A C T

Keywords

Submergence,

Cultivars, Dry matter,

Nutrient uptake,

Nitrogen.

Article Info

Accepted:

28 September 2017

Available Online:

10 November 2017
The present investigation was conducted to study the nutrient uptake of different rice varieties grown under waterlogged and submerged condition during the Kharif 2014. The experiment was conducted in Randomised block design with three replications. The result indicated that total dry matter content was highest in Sabita at harvest stage $\left(1202.40 \mathrm{~g} / \mathrm{m}^{2}\right)$. The N uptake by the shoot was the maximum in Sabita also maximum at panicle dry matter content $\left(505.40 \mathrm{~g} \mathrm{~m}^{-2}\right)$. In conclusion, dry matter accumulation varied for different variety under waterlogged and submerged condition.

\section{Introduction}

Rice is one of the most important cereal crop, widely cultivated in a varied diverse ecosystem. It consists 23 percent of global cereal acreage. India is one of the world's largest producers of rice next to China. In Odisha, around $93 \%$ area is covered with rice crop during Kharif season which is generally sown in June-July and harvested in November-December. In eastern India, about 10 million hectares of area is covered with the waterlogged area where the yield of rice is only 2.4 tons/ha. It meets about 31 and 17 percent of total calories and protein requirement respectively. Hence it is considered as a staple food of $65 \%$ of Indian population. Rice production in India is an important part of the national economy. In India, lowland rice area is about 14.4 million hectare which accounts for $32.4 \%$ of the total area of the rice crop in the country. The submerged rice ecosystem in India represents $26 \%$ of the total cultivated area. Considering the rising population growth in India the expected rice requirement must be augmented to a level of 130 million tons by 2050, Paroda, (2006) informed that rice production in India 
is almost stagnant for last six years. Hence, to achieve the targeted yield under reduced area, declining impact use efficiency having limited irrigation facility in the rainfed ecosystem the appropriate varieties should be used in the lowland. The genetic yield potential of crop varieties is limited by the environment, including abiotic and biotic stresses (Oreke et al., 1999). Among the abiotic stresses mainly water logging, light and temperature, soil salinity and drought may adversely affect plant growth and performance (Dalmia and Sawhney, 2004). So the plant breeder in collaboration with the physiologist and other sister disciplines should evaluate suitably improved rice varieties with better yield potential having tolerant capacity in deepwater areas which is one of the critical needs for suitable rice production in deep water logged ecology and it will overcome a major problem for the farming community of the state. In Odisha flooding usually, occurs in 3 stages of plant growth and can last for 7 days to one month. The stipulation that flooding must be sustends for at least one month is to be distinguished deep water rice area from other flood prone areas. In the coastal belt, the water may rise up to more than $50 \mathrm{~cm}$ by tide action and the flash flood areas where rice may be temporarily submerged for only a few days. Most deep water rice survives by elongation of the stem, where as other rice type lack these characteristics and are destroyed by deepwater. The rise in water is the most important source of flooding. Monsoon rain in the water shade brings the river down in foot flood. On reaching the flat topography the flow rate slow and over bank spills of turbid silty water bring to flood the land. Prolong water logging during the rainy season for the most part of crop growth reduces tillering and growth of the normal rice crop. Erratic or early heavy rain fall results in sudden water logging in the rice field and submerges the the situation occurs in an early vegetative period.
In crop, competition occurs in communities for nutrients so there is a need of perfect evaluation of improved rice varieties in deep water areas is one of the critical needs for sustainable rice production in deepwater logged ecology. In view of above facts, the present experiment was planned and conducted in the Adaptive Research Station, Sakhigopal, Puri during the wet season of 2012 with th objectives to evaluate "Nutrient Uptake of Different Rice Varieties Grown Under Water Logged and Submerged Condition".

\section{Materials and Methods}

The field experiment was conducted during Kharif 2014 at Adaptive Research Station, Sakhigopal, Puri, Odisha to study the biochemical traits of different rice varieties grown under waterlogged and submerged conditions. The soil of experimental field of Sakhigopal farm is clay loam and texture slightly acidic in nature. The location is situated in $19^{\circ} 48^{\prime}$ North latitude and $85^{\circ} 52^{\prime}$ East longitude $20 \mathrm{~km}$ away from the Bay of Bengal with an altitude of $6 \mathrm{~m}$ amsl. The climate is relatively warm and humid in nature with short mild winter. The average annual rainfall of the region is $1408.8 \mathrm{~mm}$ which is received from southwest monsoon. Rice varieties taken as treatments in the experiment were Sabita,FR-43B Jalamgna, OR-2331/14, IR 85085 SUB-17, Jayanti Dhana, Jalamani, CR dhan-500, CR dhan401, CR dhan-505, Mahalaxmi, Manika, CR dhan-1030, OR-142/99, Tanmayee, Urbashi, Salibahana, Rambha, OR/2328/05, Mayurakantha, Kalasira, Bankoi. The nursery bed was developed for planting of 22 varieties of rice as mentioned above. Required amount of FYM and phosphatic fertilizers were well mixed with the soils of nursery for development of fertility of soil, before date of sowing. The twenty two varieties were sown by in lines with keeping appropriate spacing 
between the varieties. The irrigation channels were kept surrounding the speed beds. Frequent sprinkler irrigation was given for seed bed initially and after germination management was done in such a manner that the raised seed bed remained moistened without any standing water over its surface for one week. Thereafter standing water was maintained up to $3 \mathrm{~cm}$. For the better growth of seedlings minimum $\mathrm{N}$-fertilizer was given in seed bed. Before 7 days of rooting of seedling granular pesticide as per as recommendation was applied in seed bed in order to avoid the infection of disease and pest after the transplanting. After 21 days of sowing the seedling was up rooted for trans planting. 3.5.2 Land preparation the main land $(50 \mathrm{mx} 40 \mathrm{~m})$ was ploughed with tractor after harvest of the previous crop. The FYM @ 5ton/ha was applied over the field. Again the yield was cross ploughed and leveled properly. Two days prior to transplanting for each sowing the irrigation was given to a plot size of 400 sq.m $(50 \mathrm{mlx} 8 \mathrm{~m})$ for puddling by the power tiller and a little standing water was maintained in the field. Further, main plot (50mx8m) was divided into three stripes representing three replication. Each replication was subdivided into 22 subplots for the allocation of varieties. 3.5.3 Fertilizer application before transplanting of seedlings and basal dose of $15 \mathrm{Kg} \mathrm{N}, 30 \mathrm{Kg} \mathrm{P}_{2} \mathrm{O}_{5}$ and $30 \mathrm{Kg} \mathrm{K} \mathrm{K}_{2} \mathrm{O}$ per hectare were applied and mixed thoroughly in soil during puddling. Rest nitrogen was top dressed twice. The first top dressing of nitrogen@ $30 \mathrm{Kg} / \mathrm{ha}$ in the form of urea was applied after 15 days of trans planting. The second top dressing of nitrogen@15 Kg/ha in the form of urea was applied at 112 days after transplanting. Twenty one days of old seedlings of rice varieties were transplanted with a spacing of $20 \mathrm{~cm} \times 10 \mathrm{~cm}$ having two seedlings per hill. Hand weeding was done at 15 days and 35 days after transplanting. Due to water logged condition, the weed population was minimum and suppressed. To control the insect and pests thaiman granule @ $10 \mathrm{Kg} / \mathrm{ha}$ was applied along with the first top dressing of nitrogen. After receding of submergence stem borer attack was observed and monocrotophos 11/ha were applied. The crop was harvested on $30^{\text {th }}$ December 2014 after it attains physiological maturity. The plant material for the nutrient evaluation was collected from five randomly selected competitive plants in each replication for all the parameter at growing stage and tagged for recording a representative sample of the entire population. After harvesting, grains were collected to determine the nutrient uptake.

The nitrogen content of different plant parts at heading and grain maturity were estimated following the procedure of A.O.A.C., (2000). Shoot dry matter and its partitioning at successive growth stages. Two hills from each plot covering an area of $200 \mathrm{sq} \mathrm{m}$. were randomly uprooted at heading and maturity stages for morpho-physiological observations. The plants were separated into roots, stems (leaf sheath+ culm), leaves (leaf blades) and panicles. The leaf area was measured by multiplying apparent leaf area (length and maximum breadth) with constant leaf area factor i.e., 0.725 at vegetative stage, 0.80at maturity (Yoshida, 1981).

The plant parts were dried separately in a hot air oven at $900 \mathrm{C}$ for 48 hours. The dry weight of different plant parts was recorded at each growth stage and expressed in $\mathrm{g} / \mathrm{m} 2$. Then it was ground to powder for further laboratory analysis.

\section{Results and Discussion}

The total dry matter content at 90 DAS i.e. before the submergence was highest in IR85085 sub-17 (1465.74 g/m2) at the same time the lowest dry matter was shown by Mayurakantha (1202.85 g/m2). 
Table.1 Variation in shoot dry matter partitioning at harvest in response to submergence condition in different rice cultivars

\begin{tabular}{|c|c|c|c|}
\hline Variety & 90 Days $\mathrm{gm} \mathrm{m}^{-2}$ & 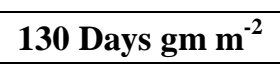 & At Harvest gm $\mathrm{m}^{-2}$ \\
\hline Sabita & 1447.78 & $\begin{array}{c}1121.04 \\
(-22.57 \%)\end{array}$ & $\begin{array}{c}1202.40 \\
(+6.77 \%)\end{array}$ \\
\hline FR-43B & 1458.75 & $\begin{array}{c}1124.01 \\
(-22.95 \%)\end{array}$ & $\begin{array}{c}1201.93 \\
(+6.48 \%)\end{array}$ \\
\hline Jalamgna & 1451.02 & $\begin{array}{c}1108.50 \\
(-23.61 \%)\end{array}$ & $\begin{array}{c}1203.77 \\
(+7.91 \%)\end{array}$ \\
\hline OR-2331/14 & 1456.93 & $\begin{array}{c}1122.44 \\
(-22.96 \%)\end{array}$ & $\begin{array}{c}1200.47 \\
(+6.50 \%)\end{array}$ \\
\hline IR 85085 SUB-17 & 1465.74 & $\begin{array}{c}1119.74 \\
(-23.61 \%)\end{array}$ & $\begin{array}{c}1195.70 \\
(+6.35 \%)\end{array}$ \\
\hline JayantiDhana & 1426.49 & $\begin{array}{c}1116.19 \\
(-21.75 \%) \\
\end{array}$ & $\begin{array}{c}1191.13 \\
(+6.29 \%) \\
\end{array}$ \\
\hline Jalamani & 1438.85 & $\begin{array}{c}1099.21 \\
(-23.60 \%) \\
\end{array}$ & $\begin{array}{c}1197.80 \\
(+8.23 \%) \\
\end{array}$ \\
\hline CR dhan-500 & 1440.35 & $\begin{array}{c}1107.12 \\
(-23.14 \%) \\
\end{array}$ & $\begin{array}{c}1197.23 \\
(+7.53 \%) \\
\end{array}$ \\
\hline CR dhan-401 & 1350.41 & $\begin{array}{c}1037.19 \\
(-23.19 \%)\end{array}$ & $\begin{array}{c}1199.33 \\
(+13.52 \%)\end{array}$ \\
\hline CR dhan-505 & 1446.26 & $\begin{array}{c}1111.66 \\
(-23.14 \%)\end{array}$ & $\begin{array}{c}1201.30 \\
(+7.46 \%)\end{array}$ \\
\hline Mahalaxmi & 1713.69 & $\begin{array}{c}1071.71 \\
(-37.46 \%) \\
\end{array}$ & $\begin{array}{c}1192.80 \\
(+10.15 \%)\end{array}$ \\
\hline Manika & 1429.55 & $\begin{array}{c}1112.50 \\
(-22.18 \%)\end{array}$ & $\begin{array}{c}1194.77 \\
(+6.89 \%) \\
\end{array}$ \\
\hline CR dhan-1030 & 1424.25 & $\begin{array}{c}1110.96 \\
(-22.00 \%)\end{array}$ & $\begin{array}{c}1191.60 \\
(+6.77 \%) \\
\end{array}$ \\
\hline OR-142/99 & 1420.31 & $\begin{array}{c}1091.71 \\
(-23.14 \%)\end{array}$ & $\begin{array}{c}1198.63 \\
(+8.92 \%)\end{array}$ \\
\hline Tanmayee & 1377.05 & $\begin{array}{c}1086.01 \\
(-21.14 \%)\end{array}$ & $\begin{array}{c}1200.17 \\
(+9.51 \%)\end{array}$ \\
\hline Urbashi & 1383.77 & $\begin{array}{c}1075.19 \\
(-22.30 \%) \\
\end{array}$ & $\begin{array}{c}1162.80 \\
(+7.53 \%) \\
\end{array}$ \\
\hline Salibahana & 1243.82 & $\begin{array}{c}980.85 \\
(-21.14 \%) \\
\end{array}$ & $\begin{array}{c}1167.60 \\
(+15.99 \%) \\
\end{array}$ \\
\hline Rambha & 1392.05 & $\begin{array}{c}1096.10 \\
(-21.26 \%)\end{array}$ & $\begin{array}{c}1178.76 \\
(+7.01 \%)\end{array}$ \\
\hline OR/2328/05 & 1388.48 & $\begin{array}{c}1072.19 \\
(-22.78 \%) \\
\end{array}$ & $\begin{array}{c}1157.23 \\
(+7.35 \%) \\
\end{array}$ \\
\hline Mayurakantha & 1202.85 & $\begin{array}{c}956.63 \\
(-20.47 \%) \\
\end{array}$ & $\begin{array}{c}1108.83 \\
(+13.73 \%)\end{array}$ \\
\hline Kalasira & 1259.09 & $\begin{array}{c}1007.28 \\
(-20.00 \%) \\
\end{array}$ & $\begin{array}{c}1090.30 \\
(+7.61 \%) \\
\end{array}$ \\
\hline Bankoi & 1276.68 & $\begin{array}{c}1013.24 \\
(-20.63 \%) \\
\end{array}$ & $\begin{array}{c}1095.40 \\
(+7.50 \%) \\
\end{array}$ \\
\hline SEM & 72.35 & 14.41 & 4.93 \\
\hline C.D 5\% & 206.48 & 41.12 & 14.06 \\
\hline C.V & 8.92 & 1.70 & 0.72 \\
\hline
\end{tabular}


Table.2 Variation in shoot dry matter partitioning at harvest in response to submergence condition in different rice cultivars

\begin{tabular}{|c|c|c|c|c|}
\hline Variety & Stem DM $\left(\mathrm{g} / \mathrm{m}^{2}\right)$ & Leaf DM $\left(\mathrm{g} / \mathrm{m}^{2}\right)$ & Panicle DM $\left(\mathrm{g} / \mathrm{m}^{2}\right)$ & Shoot DM $\left(\mathrm{g} / \mathrm{m}^{2}\right)$ \\
\hline Sabita & $\begin{array}{c}456.52 \\
(37.96 \%)\end{array}$ & $\begin{array}{c}240.48 \\
(20.00 \%)\end{array}$ & $\begin{array}{c}505.40 \\
(42.03 \%)\end{array}$ & 1202.40 \\
\hline FR-43B & $\begin{array}{c}451.64 \\
(37.57 \%)\end{array}$ & $\begin{array}{c}246.39 \\
(20.49 \%)\end{array}$ & $\begin{array}{c}503.90 \\
(41.92 \%)\end{array}$ & 1201.93 \\
\hline Jalamgna & $\begin{array}{c}460.85 \\
(38.28 \%)\end{array}$ & $\begin{array}{c}231.12 \\
(19.19 \%)\end{array}$ & $\begin{array}{c}511.80 \\
(42.51 \%)\end{array}$ & 1203.77 \\
\hline OR-2331/14 & $\begin{array}{c}466.08 \\
(38.82 \%)\end{array}$ & $\begin{array}{c}234.09 \\
(20.24 \%)\end{array}$ & $\begin{array}{c}500.30 \\
(41.67 \%)\end{array}$ & 1200.47 \\
\hline IR 85085 SUB-17 & $\begin{array}{c}472.72 \\
(39.53 \%)\end{array}$ & $\begin{array}{c}225.98 \\
(18.89 \%)\end{array}$ & $\begin{array}{c}497.00 \\
(41.56 \%)\end{array}$ & 1195.70 \\
\hline JayantiDhana & $\begin{array}{c}479.29 \\
(40.23 \%)\end{array}$ & $\begin{array}{c}222.74 \\
(18.69 \%)\end{array}$ & $\begin{array}{c}489.10 \\
(41.06 \%)\end{array}$ & 1191.13 \\
\hline Jalamani & $\begin{array}{c}487.61 \\
(40.70 \%) \\
\end{array}$ & $\begin{array}{c}217.99 \\
(18.19 \%) \\
\end{array}$ & $\begin{array}{c}492.20 \\
(41.09 \%) \\
\end{array}$ & 1197.80 \\
\hline CR dhan-500 & $\begin{array}{c}500.63 \\
(41.79 \%)\end{array}$ & $\begin{array}{c}219.00 \\
(18.29 \%)\end{array}$ & $\begin{array}{c}477.60 \\
(39.89 \%)\end{array}$ & 1197.23 \\
\hline CR dhan-401 & $\begin{array}{c}503.90 \\
(42.01 \%)\end{array}$ & $\begin{array}{c}215.03 \\
(17.92 \%)\end{array}$ & $\begin{array}{c}480.40 \\
(40.05 \%)\end{array}$ & 1199.33 \\
\hline CR dhan-505 & $\begin{array}{c}500.66 \\
(41.67 \%)\end{array}$ & $\begin{array}{c}221.45 \\
(18.43 \%)\end{array}$ & $\begin{array}{c}479.20 \\
(39.89 \%)\end{array}$ & 1201.30 \\
\hline Mahalaxmi & $\begin{array}{c}513.56 \\
(43.05 \%) \\
\end{array}$ & $\begin{array}{c}211.14 \\
(17.70 \%)\end{array}$ & $\begin{array}{c}468.10 \\
(39.24 \%)\end{array}$ & 1192.80 \\
\hline Manika & $\begin{array}{c}514.72 \\
(43.08 \%)\end{array}$ & $\begin{array}{c}215.05 \\
(17.99 \%)\end{array}$ & $\begin{array}{c}465.00 \\
(38.91 \%)\end{array}$ & 1194.77 \\
\hline CR dhan-1030 & $\begin{array}{c}517.06 \\
(43.39 \%) \\
\end{array}$ & $\begin{array}{c}212.64 \\
(17.84 \%)\end{array}$ & $\begin{array}{c}461.90 \\
(38.76 \%) \\
\end{array}$ & 1191.60 \\
\hline OR-142/99 & $\begin{array}{c}523.87 \\
(43.70 \%)\end{array}$ & $\begin{array}{c}204.96 \\
(17.09 \%)\end{array}$ & $\begin{array}{c}469.80 \\
(39.19 \%)\end{array}$ & 1198.63 \\
\hline Tanmayee & $\begin{array}{c}544.65 \\
(45.38 \%)\end{array}$ & $\begin{array}{c}196.82 \\
(16.39 \%)\end{array}$ & $\begin{array}{c}458.70 \\
(38.21 \%)\end{array}$ & 1200.17 \\
\hline Urbashi & $\begin{array}{c}504.74 \\
(43.40 \%)\end{array}$ & $\begin{array}{c}201.16 \\
(17.29 \%)\end{array}$ & $\begin{array}{c}456.90 \\
(39.29 \%)\end{array}$ & 1162.80 \\
\hline Salibahana & $\begin{array}{c}514.55 \\
(44.06 \%) \\
\end{array}$ & $\begin{array}{c}192.65 \\
(16.49 \%) \\
\end{array}$ & $\begin{array}{c}460.40 \\
(39.43 \%) \\
\end{array}$ & 1167.60 \\
\hline Rambha & $\begin{array}{c}565.67 \\
(47.98 \%)\end{array}$ & $\begin{array}{c}149.49 \\
(12.68 \%)\end{array}$ & $\begin{array}{c}463.60 \\
(39.32 \%)\end{array}$ & 1178.76 \\
\hline OR/2328/05 & $\begin{array}{c}510.95 \\
(44.15 \%)\end{array}$ & $\begin{array}{c}189.78 \\
(16.39 \%)\end{array}$ & $\begin{array}{c}456.50 \\
(39.44 \%)\end{array}$ & 1157.23 \\
\hline Mayurakantha & $\begin{array}{c}474.13 \\
(42.75 \%)\end{array}$ & $\begin{array}{c}201.80 \\
(18.19 \%)\end{array}$ & $\begin{array}{c}432.90 \\
(39.04 \%)\end{array}$ & 1108.83 \\
\hline Kalasira & $\begin{array}{c}467.74 \\
(42.90 \%)\end{array}$ & $\begin{array}{c}172.26 \\
(15.79 \%)\end{array}$ & $\begin{array}{c}450.03 \\
(41.27 \%)\end{array}$ & 1090.30 \\
\hline Bankoi & $\begin{array}{c}442.40 \\
(40.38 \%)\end{array}$ & $\begin{array}{c}204.30 \\
(18.65 \%)\end{array}$ & $\begin{array}{c}448.70 \\
(40.96 \%)\end{array}$ & 1095.40 \\
\hline SEM & 0.03 & 0.44 & 0.80 & 0.28 \\
\hline C.D 5\% & 0.08 & 1.26 & 2.29 & 0.80 \\
\hline C.V & 0.01 & 0.36 & 0.29 & 0.04 \\
\hline
\end{tabular}


Table.3 Nitrogen uptake by shoot before and after submergence in different rice cultivars

\begin{tabular}{|c|c|c|c|}
\hline \multirow{2}{*}{ Variety } & \multicolumn{3}{|c|}{ Nitrogen Uptake (g/m2) } \\
\hline & BS (75 DAS) & AS (90 DAS) & At Harvest \\
\hline Sabita & 5.52 & $\begin{array}{c}4.83 \\
(-12.48 \%) \\
\end{array}$ & $\begin{array}{c}3.86 \\
(-30.06 \%)\end{array}$ \\
\hline FR-43B & 5.44 & $\begin{array}{c}4.75 \\
(-12.65 \%)\end{array}$ & $\begin{array}{c}3.44 \\
(-30.23 \%)\end{array}$ \\
\hline Jalamgna & 5.40 & $\begin{array}{c}4.70 \\
(-12.90 \%)\end{array}$ & $\begin{array}{c}3.67 \\
(-31.90 \%)\end{array}$ \\
\hline OR-2331/14 & 5.40 & $\begin{array}{c}4.67 \\
(-13.45 \%) \\
\end{array}$ & $\begin{array}{c}3.67 \\
(-31.95 \%) \\
\end{array}$ \\
\hline IR 85085 SUB-17 & 5.36 & $\begin{array}{c}4.63 \\
(-13.50 \%) \\
\end{array}$ & $\begin{array}{c}3.62 \\
(-32.35 \%) \\
\end{array}$ \\
\hline JayantiDhana & 5.34 & $\begin{array}{c}4.54 \\
(-14.80 \%) \\
\end{array}$ & $\begin{array}{c}3.60 \\
(-32.55 \%) \\
\end{array}$ \\
\hline Jalamani & 5.35 & $\begin{array}{c}4.53 \\
(15.15 \%)\end{array}$ & $\begin{array}{c}3.60 \\
(-32.70 \%)\end{array}$ \\
\hline CR dhan-500 & 5.33 & $\begin{array}{c}4.43 \\
(16.89 \%) \\
\end{array}$ & $\begin{array}{c}3.56 \\
(-33.15 \%)\end{array}$ \\
\hline CR dhan-401 & 5.28 & $\begin{array}{c}4.42 \\
(16.29 \%) \\
\end{array}$ & $\begin{array}{c}3.49 \\
(-33.80 \%) \\
\end{array}$ \\
\hline CR dhan-505 & 5.27 & $\begin{array}{c}4.42 \\
(-16.13 \%) \\
\end{array}$ & $\begin{array}{c}3.48 \\
(-33.95 \%) \\
\end{array}$ \\
\hline Mahalaxmi & 5.25 & $\begin{array}{c}4.40 \\
(-16.19 \%)\end{array}$ & $\begin{array}{c}3.45 \\
(-34.20 \%)\end{array}$ \\
\hline Manika & 5.25 & $\begin{array}{c}4.40 \\
(-16.19 \%)\end{array}$ & $\begin{array}{c}3.42 \\
(-34.80 \%)\end{array}$ \\
\hline CR dhan-1030 & 5.14 & $\begin{array}{c}4.27 \\
(-16.80 \%)\end{array}$ & $\begin{array}{c}3.42 \\
(-34.90 \%)\end{array}$ \\
\hline OR-142/99 & 5.13 & $\begin{array}{c}4.25 \\
(-17.00 \%) \\
\end{array}$ & $\begin{array}{c}3.32 \\
(-35.16 \%) \\
\end{array}$ \\
\hline Tanmayee & 5.13 & $\begin{array}{c}4.24 \\
(-17.30 \%)\end{array}$ & $\begin{array}{c}3.30 \\
(-35.53 \%)\end{array}$ \\
\hline Urbashi & 5.10 & $\begin{array}{c}4.18 \\
(-17.88 \%)\end{array}$ & $\begin{array}{c}3.28 \\
(-35.66 \%)\end{array}$ \\
\hline Salibahana & 5.09 & $\begin{array}{c}4.17 \\
(17.91 \%) \\
\end{array}$ & $\begin{array}{c}3.27 \\
(-35.70 \%) \\
\end{array}$ \\
\hline Rambha & 4.97 & $\begin{array}{c}4.07 \\
(-18.10 \%)\end{array}$ & $\begin{array}{c}3.17 \\
(-36.10 \%)\end{array}$ \\
\hline OR/2328/05 & 4.80 & $\begin{array}{c}3.92 \\
(-18.25 \%)\end{array}$ & $\begin{array}{c}3.06 \\
(-36.25 \%)\end{array}$ \\
\hline Mayurakantha & 4.65 & $\begin{array}{c}3.77 \\
(-18.91 \%)\end{array}$ & $\begin{array}{c}2.95 \\
(-36.39 \%)\end{array}$ \\
\hline Kalasira & 4.60 & $\begin{array}{c}3.71 \\
(-19.30 \%) \\
\end{array}$ & $\begin{array}{c}2.91 \\
(-36.54 \%) \\
\end{array}$ \\
\hline Bankoi & 4.44 & $\begin{array}{c}3.56 \\
(-19.80 \%) \\
\end{array}$ & $\begin{array}{c}2.81 \\
(-36.66 \%)\end{array}$ \\
\hline Sem & 0.06 & 0.07 & 0.30 \\
\hline C.D 5\% & 0.18 & 0.02 & 0.86 \\
\hline C.V & 2.16 & 2.80 & 15.91 \\
\hline
\end{tabular}


It was observed that the dry matter content after 12 days of complete submergence there was degeneration of the plant parts and there was reduction of dry matter ranging from $20.00 \%$ to $37.46 \%$ (Table 1 ). When observed at 130 DAS the maximum dry matter content after submergence was contributed by FR43B $(11.24 .01 \mathrm{~g} / \mathrm{m} 2)$ whereas minimum value was exhibited by Salibahana $(980.85 \mathrm{~g} / \mathrm{m} 2)$.

It was noted that due to regeneration capacity of the different genotypes the dry matter accumulation was increased and the highest dry matter content at harvesting stage was contributed by Jalamagna (1203.77 g/m2) whereas minimum value of the same was shown in Kalasira (1090.30 g/m2)

The percentage of increase range from $6.29 \%$ to $15.99 \%$ as compared to 130 DAS. As regards to mean dry matter contribution of the plant parts it was noted that highest dry matter contribution at harvest was contributed by panicle which ranges from $38.21 \%$ in Tanmai to $42.21 \%$ in Jalamagna followed by stem and finally leaf. Among the cultivars highest stem and leaf dry matter was contributed by Sabita but panicle dry matter contribution was highest in Jalamagna (Table 2).

\section{Panicle $>$ Stem $>$ Leaf}

In the present investigation, it was found that the total dry matter accumulation before the submergence was highest in IR85085 sub-17 $(1465.74 \mathrm{~g} / \mathrm{m} 2)$ followed by FR-43B (1458.75 $\mathrm{g} / \mathrm{m} 2$ ) whereas after the submergence it was highest in tolerant genotype FR-43B $(1124.01 \mathrm{~g} / \mathrm{m} 2)$ followed by OR-2331/14 $(1122.44 \mathrm{~g} / \mathrm{m} 2)$ and Sabita (1121.04 g/m2) respectively in Table 2 . The genotypes having higher dry mass can withstand submergence and have better regeneration capacity because the dry matter accumulation after the submergence is highly correlated with the survival percentage (Sarkar et al., 2006).
From the data it was revealed that the mean nitrogen uptake by the stem and leaf before the submergence was greater than their mean nitrogen uptake after the submergence. The mean $\mathrm{N}$-uptake was highest in Sabita (5.52 $\left.\mathrm{g} / \mathrm{m}^{2}\right)$ followed by FR-43B (5.44 $\left.\mathrm{g} / \mathrm{m}^{2}\right)$ whereas the lowest value was recorded in Bankoi $\left(4.44 \mathrm{~g} / \mathrm{m}^{2}\right)$ before the submergence. Data recorded after the submergence indicated that higher $\mathrm{N}$-uptake was exhibited by Sabita $\left(4.83 \mathrm{~g} / \mathrm{m}^{2}\right)$ and lowest value was shown in Bankoi $\left(3.56 \mathrm{~g} / \mathrm{m}^{2}\right)$ with a reduction of $12.48 \%$ and $19.80 \%$ respectively as compared to before submergence (Table 3). At harvesting $\mathrm{N}$-uptake was maximum in panicle as compared to other plantparts irrespective of genotypes. The maximum $\mathrm{N}$ uptake was exhibited by Sabita $\left(3.86 \mathrm{~g} / \mathrm{m}^{2}\right)$ and lowest in Bankoi $\left(2.81 \mathrm{~g} / \mathrm{m}^{2}\right)$. From the C.V. value it was found that there was no wide variation among the varieties as regards to $\mathrm{N}$ uptake by the plant. The photosynthesis activity of leaves depends upon the essential nutrient content of the leaf and stem. In general the nitrogen content of the shoot decreased when the crop was subjected to submergence. The nitrogen content of the shoot ranged from $5.27 \mathrm{~g} / \mathrm{m}^{2}$ to $5.52 \mathrm{~g} / \mathrm{m}^{2}$ in (Table 3) tolerant varieties whereas the susceptible variety the uptake was lower which ranged from $4.44 \mathrm{~g} / \mathrm{m}^{2}$ to $5.13 \mathrm{~g} / \mathrm{m}^{2}$. After submergence due to damage of plant parts the uptake of nitrogen was reduced to a tune of $12.43 \%$ to $16.13 \%$ in tolerant cultivars but in susceptible cultivars it was $17.00 \%$ to $19.80 \%$ depending upon the genotypes. Due to regeneration capacity of the tolerant cultivar the nitrogen content increased more than susceptible cultivars

It was revealed that the nitrogen uptake before the submergence was maximum in Sabita (5.52 $\left.\mathrm{g} / \mathrm{m}^{2}\right)$ followed by FR-43B $\left(5.44 \mathrm{~g} / \mathrm{m}^{2}\right)$, Jalamgna and OR-2331/14 $\left(5.40 \mathrm{~g} / \mathrm{m}^{2}\right)$. Among the cultivars the maximum shoot dry matter was recorded from Jalamagna (1203.77 g/m²) 
followed by Sabita $\left(1202.40 \mathrm{~g} / \mathrm{m}^{2}\right)$. It is concluded that sabita,FR-43B, Jalamagna cultivars are recommended for grown waterlogged and submergence condition.

\section{References}

A.O.A.C.2000. Official method of analysis. Association of Official Analytical Chemists. 17th Ed. Inc., Maryland, USA.

Dalmia A. and Sawhney V. 2004. Antioxidant defense mechanism under drought stress in wheat seedlings. Physiol. Mol. Biol. Plant, 10(1):109114.

Oreke ECC, Weber A., Dehne WH. 1999. Crop production and crop protection: Elsevier, Amsterdam

Sarkar RK, Reddy 2006. Physiological traits on submergence tolerance rice and implication for crop improvement, Current Science, 91(7).829-905

Yoshida S. 1981. Fundamental of Crop science. Intl. Rice Res. Institute, Los Banos, Leguna, Phillipines.269p

\section{How to cite this article:}

Das, B., A.K. Padhiary, S. Behera, S.P. Mishra, M. Jena, S.C. Swain and Rout, S.K. 2017. Partitioning of Dry Matter in Different Rice Varieties in Response to Water Logged and Submerged Condition. Int.J.Curr.Microbiol.App.Sci. 6(11): 4037-4044. doi: https://doi.org/10.20546/ijcmas.2017.611.472 